\title{
Enzymes of the Tricarboxylic Acid Cycle in Acetic Acid Bacteria
}

\author{
By P. J. LE B. WILLIAMS* and C. RAINBOW \\ Department of Biochemistry, University of Birmingham
}

(Received 1 November 1963)

\begin{abstract}
SUMMARY
The activities of seven enzymes which catalyse reactions of the tricarboxylic acid cycle were assayed in extracts of five lactaphilic and five glycophilic strains of acetic acid bacteria. Except for isocitrate dehydrogenase (which was not detected in glycophilic extracts) all other enzymes were found in all strains; but in general these enzymes were much more abundant in the lactaphilic extracts. In particular, extracts of glycophiles possessed only feeble citrate synthase, aconitate hydratase, fumarate hydratase and L-malate dehydrogenase activities and only their 2oxoglutarate and succinate dehydrogenase activities were comparable to the corresponding activities in extracts of lactaphiles. Oxaloacetate decarboxylase activity was also greater in lactaphiles than in glycophiles. Two enzymes which oxidized L-malate were found: that in Acetobacter acidum-mucosum was an NADP-linked dehydrogenase, while the other more generally distributed enzyme required no added co-factors and may be cytochrome-linked. The evidence indicates that the tricarboxylic acid cycle may make a greater quantitative contribution to the metabolism of lactaphilic than to that of glycophilic organisms.
\end{abstract}

\section{INTRODUCTION}

There is nutritional and biochemical evidence for distinguishing two groups of acetic acid bacteria. Members of one group (the lactaphiles) have simple nutritional requirements, grow well on lactate and whole organisms oxidize intermediates of the tricarboxylic acid (TCA) cycle and effect reversible transamination between L-aspartate and 2-oxoglutarate. Members of the other group (the glycophiles) grow on glucose but not on lactate, have somewhat more complex nutritional requirements, and their ability to effect aspartate-2-oxoglutarate transamination and to oxidize TCA cycle intermediates is poorly developed or absent (Rainbow \& Mitson, 1953; Brown \& Rainbow, 1956; Cooksey \& Rainbow, 1962). The lactaphiles and glycophiles thus distinguished correspond respectively to the genera Acetobacter and Acetomonas recognized by Leifson (1954) and by Shimwell (1958) on the criteria of flagellation and ability to oxidize acetate.

From their results, Cooksey \& Rainbow (1962) suggested that the lactaphiles, but perhaps not the glycophiles, possessed an operative TCA cycle. The present work was designed to assess TCA cycle activity in acetic acid bacteria, as indicated by the individual activities of seven enzymes of the cycle in cell extracts, and so to test out this hypothesis.

\footnotetext{
* Present address: Division of Applied Biology, National Research Council, Ottawa, Canada.
} 


\section{METHODS}

Materials. Substrates were commercially available preparations. Before use in enzyme reaction mixtures, organic acids were adjusted with $\mathrm{KOH}$ solution to the $\mathrm{pH}$ value of the reaction mixture. Acetyl coenzyme A was synthesized by the method of Stadtman (1957).

Test organisms and cultivation. The organisms used were the strains of Acetobacter studied by Cooksey \& Rainbow (1962) and a strain of $A$. suboxydans, which was derived from the original strain of Kluyver \& van Leeuw and kindly given by Dr J. L. Shimwell (British Vinegars Ltd, Frome).

Experimental cultures were grown at $28^{\circ}$ until good growth was obtained (2-7 days) in a medium having the following composition (g./100 ml.): glucose, 1 ; syrupy lactic acid (A.R.), 1; Difco yeast extract, 0.5; $\left(\mathrm{NH}_{4}\right)_{2} \mathrm{HPO}_{4}$ (A.R.), 0.2; L-glutamic acid, $0 \cdot 1 ; \mathrm{MgSO}_{4} .7 \mathrm{H}_{2} \mathrm{O}$ (A.R.), 0.05. These ingredients were dissolved in tap water and adjusted to $\mathrm{pH} 5 \cdot 8$ with $\mathrm{KOH}$ solution.

Preparation of cell extracts. After growth, organisms were harvested and washed as described by Cooksey \& Rainbow (1962) and suspended in about $5 \mathrm{ml}$. of an icecold solution of appropriate buffer. The organisms in this suspension were disrupted in the Mullard/MSE Ultrasonic Disintegrator (Measuring and Scientific Equipment Ltd., London). During disruption (usually about $30 \mathrm{~min}$.), the tube containing the material was cooled continuously in a freezing mixture. The resultant suspension was centrifuged at $15,000 \mathrm{~g}$ for $20 \mathrm{~min}$. at $0-5^{\circ}$, yielding a pale reddish-brown supernatant fluid which was used for the enzyme assays. The protein content of this liquid was determined by the method of Lowry, Rosebrough, Farr \& Randall (1951). For this determination, a solution of human plasma was used as a protein standard, the nitrogen content of this solution being determined by the microKjeldahl procedure.

Enzyme assays. The enzyme nomenclature used is that recommended in the Report of the Commission on Enzymes of the International Union of Biochemistry, Pergamon Press, 1961, but trivial names are used for the dehydrogenase systems studied, since the experimental results do not permit precise identification of the enzymes concerned. In all cases, enzyme activities were calculated from initial reaction velocities determined over a period when plots of amount of chemical change against time were linear.

Spectrophotometric assays. These were done with the SP 500 quartz spectrophotometer (Unicam Ltd., Cambridge) or with the Cary recording spectrophotometer (Applied Physics Corporation, Monrovia, California). Fumarate hydratase (Lmalate hydro-lyase, EC 4.2.1.2) and aconitate hydratase [citrate (isocitrate) hydro-lyase, EC 4.2.1.3] activities were assayed by a method based on that of Racker (1950), depending on measurement of increase in extinction at $240 \mathrm{~m} \mu$ attendant on the conversion of L-malate to fumarate by fumarate hydratase and of citrate to cis-aconitate by aconitate hydratase. Citrate synthase (citrate oxaloacetate-lyase, EC 4.1.3.6) and malate synthase (L-malate glyoxylate-lyase, EC 4.1.3.2) activities were determined by a method based on that applied for malate synthase activity by Dixon \& Kornberg (1959), in which progress of the reaction is followed by the fall in optical density at $232 \mathrm{~m} \mu$ attendant on the cleavage of the thioester bond of acetyl coenzyme $A$ during reaction with oxaloacetate. The 
method was also applied to determine isocitrate lyase $\left(\mathrm{L}_{\mathrm{B}}\right.$-isocitrate glyoxylatelyase, EC 4.1.3.1) activity, the glyoxylate formed from isocitrate being converted to its phenylhydrazone, which was measured at $324 \mathrm{~m} \mu$. L-Malate and 2-oxoglutarate dehydrogenase systems were assayed by measuring at $600 \mathrm{~m} \mu$ the loss of colour on reduction of 2·6-dichlorophenol-indophenol (DCPIP; Sanadi \& Littlefield, 1951), and NADP-linked L-malate and isocitrate dehydrogenase systems by measurement of the increase in optical density at $340 \mathrm{~m} \mu$ on reduction of NADP (Rao, 1955).

Manometric assays. These were done with a conventional Warburg constantvolume respirometer technique. Succinate dehydrogenase activity and L-malate oxidation were assayed by measurement of oxygen uptake, the former with succinate as substrate in the presence of phenazine methosulphate as electron carrier (Singer \& Kearney, 1957) and the latter with L-malate as substrate. Oxaloacetate decarboxylase (oxaloacetate carboxy-lyase, EC 4.1.1.3) activity was measured in terms of rate of evolution of $\mathrm{CO}_{2}$ from oxaloacetate.

Chromatography. Whatman No. 1 paper was used in conventional one-dimensional descending and ascending techniques. Oxo acids were chromatographed as their 2,4-dinitrophenylhydrazones in an ascending system as described by Smith (1958). The position of the acids was indicated by a brown area on a pale brown background.

\section{RESULTS}

\section{Citrate synthase activities}

By using the method of Ochoa, Stern \& Schneider (1951), Cooksey \& Rainbow (1962) readily detected citrate synthase in extracts of lactaphilic, but not in those of glycophilic, acetic acid bacteria. However, with this method, low citrate synthase activity might be overlooked in extracts possessing oxaloacetate decarboxylase activity because of decomposition of the oxaloacetate substrate. Consequently, the method of Dixon \& Kornberg (1959), which is more sensitive and is not complicated by enzymic decarboxylation of oxaloacetate, was used to determine citrate synthase activities. The results (Table 1) show that activity was detected in extracts of glycophiles, but that the activity of all the lactaphiles far exceeded that of the most potent glycophile.

\section{Aconitate hydratase and fumarate hydratase activities}

Extracts of all the test strains possessed fumarate hydratase and aconitate hydratase activities, although those of the lactaphilic strains were considerably greater than those of glycophilic strains (Table 2). The fumarate hydratase and aconitate hydratase activities of Acetobacter mobile, while feebler than those of other lactaphiles, nevertheless exceeded those of any glycophile. Extracts from $A$. rancens showed a broad optimum of fumarate hydratase activity over the range $\mathrm{pH} 7 \cdot 2$ 7.6. Activity was partially inhibited by $0.001 \mathrm{M}$-malonate, $0.017 \mathrm{M}-\mathrm{D}$-malate and by $0.01 \mathrm{~m}$-fluoride, but not by dialysis. In these properties, the enzyme resembled that prepared from other sources (Massey, $1953 a, b$ ). The properties of the aconitate hydratase of $A$. rancens resembled those of the mammalian enzyme (Morrison, 1954) in that activity was optimal over the range $\mathrm{pH} 7 \cdot 0-7 \cdot 6$ and dialysis caused partial inhibition, which was annulled by addition of $0 \cdot 003 \mathrm{M}-\mathrm{Fe}^{2+}$. 


\section{Succinate dehydrogenase activities}

Table 3 shows that extracts of all test organisms possessed succinate dehydrogenase activity. In general, extracts of lactaphiles were more active than those of glycophiles, but the difference between the two groups was not great.

\section{Table 1. Citrate synthase activities of cell extracts of acetic acid bacteria}

Reactions were carried out at $22^{\circ}$ and $\mathrm{pH} \gamma \cdot 1$ in $1 \mathrm{~cm}$. quartz cuvettes containing, in a final volume of $1.5 \mathrm{ml}$.: cell extract; tris buffer (pH $7 \cdot 1 ; 50 \mu$ mole); oxaloacetate (2 $\mu$ mole); $\mathrm{MgCl}_{2}(2 \mu \mathrm{mole})$; and acetyl coenzyme $\mathrm{A}$ (0.1 $\mu$ mole), addition of which was used to start the reaction. Progress of the reaction was followed by fall in extinction at $232 \mathrm{~m} \mu\left(\mathbf{E}_{282}\right)$. Activity is given as $\mu$ mole of acetyl coenzyme A hydrolysed $/ \mathrm{hr} / \mathrm{mg}$. protein. The fall in $E_{232}$ on hydrolysis of $1 \mu$ mole of acetyl coenzyme $A$ in 1.5 ml. of water is $\mathbf{3} \cdot \mathbf{0}$.

\begin{tabular}{|c|c|c|c|}
\hline Extract & $\begin{array}{c}\text { Protein added } \\
\text { (mg.) }\end{array}$ & $\begin{array}{l}\text { Fall in } E_{232} \\
\text { in } 6 \text { min. }\end{array}$ & $\begin{array}{l}\text { Citrate synthase } \\
\text { activity }\end{array}$ \\
\hline \multicolumn{4}{|l|}{ Lactaphiles } \\
\hline A. acidum-mucosum & $0 \cdot 015$ & $0 \cdot 133$ & $29 \cdot 0$ \\
\hline A. ascendens & $0 \cdot 016$ & $0 \cdot 283$ & $60 \cdot 4$ \\
\hline A. mobile & $0 \cdot 015$ & $0 \cdot 044$ & $9 \cdot 6$ \\
\hline A. oxydans & 0.025 & $\mathbf{0 . 3 5 7}$ & $47 \cdot 9$ \\
\hline A. rancens & $0 \cdot 028$ & $0 \cdot 249$ & $30 \cdot 7$ \\
\hline \multicolumn{4}{|l|}{ Glycophiles } \\
\hline A. capsulatum & $0 \cdot 090$ & $0 \cdot 008$ & 0.3 \\
\hline A. gluconicum & $0 \cdot 060$ & $0 \cdot 020$ & $1 \cdot 1$ \\
\hline A. suboxydans & $0 \cdot 062$ & $0 \cdot 018$ & $0 \cdot 9$ \\
\hline A. turbidans & 0.062 & 0.004 & $0 \cdot 2$ \\
\hline A. viscosum & 0.072 & $0 \cdot 009$ & 0.5 \\
\hline
\end{tabular}

Table 2. Aconitate hydratase and fumarate hydratase activities of extracts of acetic acid bacteria

Reactions were carried out at $22^{\circ}$ and $\mathrm{pH} 7 \cdot 0$ in $1 \mathrm{~cm}$. quartz cuvettes containing in a final volume of $3.0 \mathrm{ml}$.: cell extract; potassium phosphate buffer (pH 7.0; $50 \mu$ mole); and substrate ( $50 \mu$ mole). The reaction was started by addition of substrate ( $L$-malate for fumarate hydratase or citrate for aconitate hydratase activity) and progress of the reaction was followed by increase in extinction at $240 \mathrm{~m} \mu\left(\mathrm{E}_{240}\right)$. Activity is given as $\mu$ moles of fumarate or cis-aconitate formed $/ \mathrm{hr} / \mathrm{mg}$. protein. In $3.0 \mathrm{ml}$. of water, the extinction of $240 \mathrm{~m} \mu$ of $1 \mu$ mole of fumarate and of $1 \mu$ mole of cis-aconitate are 0.703 and 1.18 respectively.

\begin{tabular}{|c|c|c|c|c|c|}
\hline & & Fumarate $h$ & dratase & Aconitate $\mathbf{h}$ & dratase \\
\hline Extract from & $\begin{array}{l}\text { added } \\
\text { (mg.) }\end{array}$ & $\begin{array}{c}\text { Increase in } E_{240} \\
\text { after } \\
10 \mathrm{~min} .\end{array}$ & Activity & $\begin{array}{c}\text { Increase in } E_{240} \\
\text { after } \\
10 \mathrm{~min} .\end{array}$ & Activity \\
\hline Lactaphiles & & & & & \\
\hline A. acidum-mucosum & $0 \cdot 103$ & $0 \cdot 105$ & 8.7 & $0 \cdot 332$ & $16 \cdot 4$ \\
\hline A. ascendens & $0 \cdot 101$ & $0 \cdot 159$ & $13 \cdot 2$ & $0 \cdot 261$ & $13 \cdot 1$ \\
\hline A. mobile & 0.091 & 0.041 & $3 \cdot 8$ & 0.026 & $1 \cdot 2$ \\
\hline 1. oxydans & 0.112 & $\mathbf{0} \cdot \mathbf{3 1 2}$ & $23 \cdot 7$ & 0.356 & $16 \cdot 1$ \\
\hline A. rancens & $0 \cdot 101$ & $0 \cdot 127$ & $10 \cdot 7$ & 0.236 & $11 \cdot 8$ \\
\hline Glycophiles & & & & & \\
\hline A. capsulatum & $0 \cdot 202$ & 0.011 & 0.4 & 0.006 & $0 \cdot 1$ \\
\hline A. gluconicum & $0 \cdot 130$ & $0 \cdot 007$ & $0 \cdot 5$ & $0 \cdot 009$ & 0.4 \\
\hline A. suboxydans & $0 \cdot 101$ & 0.015 & $1 \cdot 3$ & 0.007 & $0 \cdot 4$ \\
\hline A. turbidans & 0.273 & 0.034 & $1 \cdot 1$ & 0.018 & 0.3 \\
\hline A. viscosum & 0.274 & 0.028 & 0.9 & 0.017 & $0 \cdot 3$ \\
\hline
\end{tabular}




\section{Table 3. Succinate dehydrogenase activities of extracts of acetic acid bacteria}

Warburg vessels contained in $3 \mathrm{ml}$. final volume: cell extract; phosphate buffer (pH 7.6; $150 \mu$ mole); potassium succinate (pH 7.6; $150 \mu$ moles added from side arm); phenazine methosulphate ( $2 \mathrm{mg}$. added from side arm); KCN (3 $\mu$ mole, pH 7·6). Reactions were carried out at $37^{\circ}$ in subdued light and followed by uptake of oxygen, corrections being made in each case for the small volume of gas (1.5-10 $\mu 1$.) evolved by the extract. Activity is given as $\mu$ mole $\mathrm{O}_{2}$ absorbed $/ \mathrm{hr} / \mathrm{mg}$. protein.

\begin{tabular}{|c|c|c|c|}
\hline Extract from & $\begin{array}{c}\text { Protein added } \\
\text { (mg.) }\end{array}$ & $\underset{\mathbf{h r}}{\mu \mathrm{l} . \mathrm{O}_{\mathbf{2}} \text { absorbed/ }}$ & $\begin{array}{c}\text { Succinate } \\
\text { dehydrogenase } \\
\text { activity }\end{array}$ \\
\hline \multicolumn{4}{|l|}{ Lactaphiles } \\
\hline A. acidum-mucosum & $1 \cdot 62$ & $57 \cdot 4$ & 1.58 \\
\hline A. ascendens & $0 \cdot 78$ & 60.5 & $\mathbf{3 . 5 3}$ \\
\hline A. mobile & $1 \cdot 48$ & $74 \cdot 9$ & $2 \cdot 26$ \\
\hline A. oxydans & $1 \cdot 63$ & $46 \cdot 2$ & $1 \cdot 27$ \\
\hline A. rancens & $1 \cdot 46$ & $85 \cdot 4$ & $2 \cdot 61$ \\
\hline \multicolumn{4}{|l|}{ Glycophiles } \\
\hline A. capsulatum & $1 \cdot 32$ & 49.9 & 1.68 \\
\hline A. gluconicum & 0.83 & 24.5 & $1 \cdot 32$ \\
\hline A. suboxydans & $1 \cdot 68$ & $29 \cdot 6$ & 0.80 \\
\hline A. turbidans & 4.97 & $40 \cdot 8$ & $0 \cdot 37$ \\
\hline A. viscosum & 4.98 & $41 \cdot 8$ & $0 \cdot 38$ \\
\hline
\end{tabular}

Table 4. Nicotinamide nucleotide-linked L-malate and isocitrate dehydrogenase activities of extracts of acetic acid bacteria

Reactions were carried out at $22^{\circ}$ in $1 \mathrm{~cm}$. quartz cuvettes containing in a final volume of $0.41 \mathrm{ml}$.: tris buffer (pH 7.1; $25 \mu$ mole); L-malate or DL-isocitrate (pH 7.1; 25 $\mu$ mole); and NAD or NADP $(0 \cdot 1 \mu \mathrm{mole})$ added to initiate the reaction. Reaction was followed by increase in extinction at $340 \mathrm{~m} \mu$ $\left(\mathrm{E}_{340}\right)$. Activity is given as $\mu$ moles of reduced nicotinamide nucleotide produced $/ \mathrm{hr} / \mathrm{mg}$. protein. $1 \mu$ mole of reduced NAD or NADP in $3.0 \mathrm{ml}$. water in the $1 \mathrm{ml}$. cuvette had an $\mathrm{E}_{340}$ of 2.1 .

Isocitrate dehydrogenases

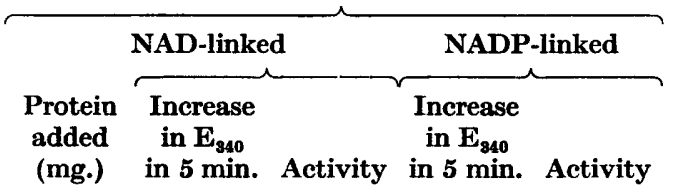

NADP-linked L-malate dehydrogenase

$\begin{array}{cc}\text { Protein } & \text { Increase } \\ \text { added } & \text { in } \mathbf{E}_{\mathbf{3 4 0}} \\ \text { (mg.) in } 5 \text { min. Activity }\end{array}$

ctaphiles

A. acidum-mucosum $\quad 0.025$

A. ascendens $\quad 0 \cdot 024$

\begin{tabular}{|c|c|c|c|c|c|}
\hline $0 \cdot 114$ & 3.59 & 0.530 & $16 \cdot 7$ & $0 \cdot 25$ & 0.277 \\
\hline $0 \cdot 104$ & $\mathbf{3 \cdot 3 6}$ & 0.553 & $17 \cdot 9$ & $1 \cdot 21$ & \\
\hline 0.274 & $2 \cdot 21$ & $0 \cdot 232$ & $1 \cdot 9$ & 0.97 & No activity \\
\hline 1.75 & $49 \cdot 8$ & 0.241 & $6 \cdot 7$ & $1 \cdot 37$ & detected over \\
\hline $0 \cdot 205$ & 5.03 & $0 \cdot 322$ & $7 \cdot 9$ & 0.44 & $10 \mathrm{~min}$. \\
\hline
\end{tabular}

A. mobile

0.097

$0 \cdot 028$

0.205

$\mathbf{0} \cdot \mathbf{3 2 2}$

$0 \cdot 4410 \mathrm{~min}$.

ycophiles: All reaction mixtures contained at least $0.5 \mathrm{mg}$. protein added as enzyme extract, but no activity was detected over $10 \mathrm{~min}$.

\section{Isocitrate dehydrogenase activities}

Both NAD- and NADP-dependent isocitrate dehydrogenases were detected in extracts of lactaphiles, but neither was detected in those of glycophiles (Table 4). However, the progress curve of the NADP-linked reaction was sigmoidal, the lag period, before maximum rate of reaction was attained, increasing with enzyme dilution. Consequently, failure to detect isocitrate dehydrogenation by extracts of glycophiles was not proof of its absence, although it did indicate that the amount 
of the enzyme in glycophilic extracts was indeed low, especially large amounts of protein having been added as extract in an attempt to detect it.

\section{Malate-oxidizing enzymes}

Several attempts to detect an NAD-dependent L-malate dehydrogenase failed, but an NADP-dependent enzyme was detected only in extracts of Acetobacter acidum-mucosum with a high protein content (Table 4). Maximum activity of this enzyme was observed at $\mathrm{pH} 7 \cdot \mathbf{0 - 7 \cdot 5}$. Activity was inhibited by dialysis, but restored by addition of $0.0003 \mathrm{M}-\mathrm{Mn}^{2+}$, and inhibited by $0.001 \mathrm{M}-p$-chloromercuribenzoate. Like isocitrate dehydrogenase, the progress curve for enzyme activity was sigmoidal, the length of the lag phase being diminished by using greater enzyme concentrations and by incubating the enzyme with $\mathrm{L}$-malate before starting the

\section{Table 5. Activities of the dichlorophenolindophenol-linked L-malate and 2-oxoglutarate dehydrogenases in extracts of acetic acid bacteria}

For L-malate dehydrogenase, reactions were carried out at $22^{\circ}$ in $1 \mathrm{~cm}$. quartz cuvettes containing in a final volume of $3.0 \mathrm{ml}$.: cell extract; tris buffer (pH 7.0; $100 \mu \mathrm{mole})$; L-malate (pH 7.0; $20 \mu$ mole); MnSO $_{4}(1 \mu$ mole); 2.6 dichlorophenolindophenol (DCPIP, $0.1 \mu$ mole, added to start the reaction). For 2-oxoglutarate dehydrogenase, reactions were carried out as above, except that $L$-malate and tris buffer were replaced by 2oxoglutarate (pH 7.0; $60 \mu$ mole) and phosphate buffer (pH 7.0; $100 \mu$ mole), $\mathrm{MnSO}_{4}$ was omitted and thiamine pyrophosphate $(2 \mu$ mole) was added. The progress of the reactions was followed by measuring the difference in extinction at $600 \mathrm{~m} \mu\left(\mathrm{E}_{800}\right)$ between the reaction mixtures and appropriate blanks consisting of the same mixtures, but lacking substrate. Activity is given as $\mu$ mole of DCPIP reduced $/ \mathrm{hr} / \mathrm{mg}$. protein. A solution containing 0.1 $\mu$ mole DCPIP per $3 \mathrm{ml}$. water had an $\mathbf{E}_{600}$ of 0.51 .

\begin{tabular}{|c|c|c|c|c|c|c|}
\hline \multirow[b]{2}{*}{ Extract from } & \multicolumn{3}{|c|}{ 2-oxoglutarate dehydrogenase } & \multicolumn{3}{|c|}{ L-malate dehydrogenase } \\
\hline & $\begin{array}{c}\text { Protein } \\
\text { added } \\
\text { (mg.) }\end{array}$ & $\begin{array}{l}\text { Fall in } \\
\mathbf{E}_{600} \text { in } \\
5 \text { min. }\end{array}$ & Activity & $\begin{array}{c}\text { Protein } \\
\text { added } \\
\text { (mg.) }\end{array}$ & $\begin{array}{l}\text { Fall in } \\
\mathbf{E}_{600} \text { in } \\
5 \text { min. }\end{array}$ & Activity \\
\hline \multicolumn{7}{|l|}{ Lactaphiles } \\
\hline A. acidum-mucosum & $\mathbf{0} \cdot \mathbf{2 5 9}$ & 0.036 & $\mathbf{0} \mathbf{3 2}$ & $\mathbf{0} \cdot \mathbf{2 4 8}$ & $0 \cdot 187$ & $1 \cdot 48$ \\
\hline A. ascendens & $0 \cdot 395$ & 0.085 & 0.51 & $0 \cdot 121$ & 0.086 & $\mathbf{1 . 3 6}$ \\
\hline A. mobile & 0.543 & 0.020 & 0.08 & 0.485 & 0.046 & $0 \cdot 19$ \\
\hline A. oxydans & $0 \cdot 370$ & 0.054 & 0.35 & 0.032 & $0 \cdot 105$ & 6.51 \\
\hline A. rancens & $0 \cdot 184$ & 0.030 & $0 \cdot 38$ & $0 \cdot 159$ & 0.041 & 0.51 \\
\hline \multicolumn{7}{|l|}{ Glycophiles } \\
\hline A. capsulatum & $0 \cdot 516$ & $\mathbf{0 . 0 3 8}$ & $\mathbf{0} \cdot 17$ & $0 \cdot 261$ & 0.040 & $\mathbf{0 \cdot 3 0}$ \\
\hline A. gluconicum & $\mathbf{0} \cdot \mathbf{2 6 0}$ & 0.012 & $0 \cdot 10$ & $0 \cdot 272$ & 0.002 & 0.01 \\
\hline A. suboxydans & 0.252 & $0 \cdot 029$ & $0 \cdot 27$ & $\mathbf{0} \cdot \mathbf{3 6 8}$ & 0.021 & $0 \cdot 11$ \\
\hline A. turbidans & $0 \cdot 353$ & $0 \cdot 062$ & 0.41 & $0 \cdot 306$ & 0.025 & $0 \cdot 16$ \\
\hline A. viscosum & $\mathbf{0} \cdot \mathbf{3 1 5}$ & $0 \cdot 075$ & 0.56 & $0 \cdot 277$ & $0 \cdot 048$ & $\mathbf{0} \cdot \mathbf{3 4}$ \\
\hline
\end{tabular}

reaction by adding NADP. Oxaloacetate was identified as a product of the reaction by paper chromatography and since the reaction was completely inhibited by 0.033 M-oxaloacetate, but not by 0.033 M-pyruvate, it appeared to be catalysed by an L-malate : NADP oxidoreductase different from the L-malate :NADP oxidoreductase (decarboxylating) (EC 1.1.1.40) found in Chromatium by Fuller \& Kornberg (1961).

Failure to detect a nicotinamide nucleotide-dependent malate-oxidizing system in strains other than Acetobacter acidum-mucosum prompted a search for an alterna- 
tive hydrogen-acceptor for L-malate oxidation. Methylene blue, 2,3,5-trimethyltetrazolium chloride and neotetrazolium chloride failed in this role, but DCPIP was suitable for the dehydrogenation of both L-malate and of 2-oxoglutarate (see below). In experiments with L-malate, the same enzyme extracts were used as for the tests for NADP-linked L-malate dehydrogenase. Oxaloacetate was detected by paper chromatography as a reaction product and the enzyme was found in extracts of lactaphiles and of glycophiles, the former, with the exception of $A$. mobile, being richer in the enzyme (Table 5).

\title{
Table 6. Oxidation of L-malate by extracts of Acetobacter rancens, A. acidum-
} mucosum and A. capsulatum

\begin{abstract}
Warburg vessels contained a final volume of $3.0 \mathrm{ml}$., made up of cell extract, tris buffer (pH $7 \cdot 1 ; 100 \mu$ mole) and the following additions as indicated: L-malate (pH $7 \cdot 1 ; 10$ $\mu$ mole); NAD (1 $\mu$ mole); DL-isocitrate (pH 7.1; $10 \mu$ mole); NADP (1 $\mu$ mole); KCN (3 $\mu$ mole; pH $7 \cdot 1)$; guanidine (30 $\mu$ mole). Temperature $28^{\circ}$. The reaction was started by adding L-malate (or DL-isocitrate) from the side arm and was followed by measurement of $\mathrm{O}_{2}$ uptake.
\end{abstract}

Extract from

A. rancens

A. acidum-mucosum

A. capsulatum
Reaction mixture

No additions
+L-malate
+ L-malate + NAD
+L-malate + NADP
No additions
+L-malate
+L-malate + KCN
+L-malate + guanidine
+L-malate + cytochrome $C$
+ DL-isocitrate
+ DL-isocitrate + NAD

No additions

+L-malate $\mu$ mole $\mathrm{O}_{2}$ $\mu l . \mathrm{O}_{2}$
absorbed $/ \mathrm{mg}$.
protein $/ \mathrm{hr}$ Added (mg.) absorbed/h

$\mathbf{0 . 0 6}$
$\mathbf{1} \cdot 63$
$\mathbf{1} \cdot 63$
$\mathbf{1 . 6 8}$
$\mathbf{0 . 0 9}$
$\mathbf{4} \cdot 96$
$\mathbf{0 . 5 0}$
$\mathbf{5 . 0 6}$
$\mathbf{4} \cdot 71$
0
0
0
$1 \cdot 23$

Manometric experiments with extracts of Acetobacter acidum-mucosum, $A$. rancens and $A$. capsulatum showed that L-malate oxidation was accompanied by uptake of oxygen (Table 6), which was unaffected by addition of NAD, NADP or cytochrome $c$, but inhibited $90 \%$ by 0.001 m-cyanide. Guanidine $(0.01 \mathrm{~m})$, which in mammalian systems inhibits electron transfer between reduced nicotinamide nucleotides and cytochrome $c$ (Hollunger, 1955), did not inhibit the reaction. In similar experiments, isocitrate was not oxidized, even when NAD was added. The possibility that the oxidation of $L$-malate was mediated by cytochromes other than cytochrome $c$ was indicated by the following experiment. An extract of $A$. acidummucosum with a high protein content $(10 \mathrm{mg}$. $/ \mathrm{ml}$.) was shaken in air to ensure that all its cytochromes were in the oxidized state. A portion of this preparation was incubated with buffered $\mathrm{L}$-malate $(\mathrm{pH} 7 \cdot 1$ ) and the absorption spectrum of the reaction mixture was plotted between 450 and $600 \mathrm{~m} \mu$, using as reference solution the same reaction mixture from which L-malate was omitted. The difference spectrum so obtained had peaks at 525 and $555 \mathrm{~m} \mu$ similar to those observed for the cytochromes of other acetic acid bacteria by Smith (1954), King \& Cheldelin (1956), Fewster (1958) and by Stouthamer (1961). No difference spectrum was obtained 
when isocitrate was substituted for L-malate in the reaction mixture. Similar results were obtained with extracts of $A$. oxydans. These results indicate that the aerobic oxidation of $\mathrm{L}$-malate by extracts of acetic acid bacteria was accompanied by spectral changes suggestive of the formation of reduced cytochromes.

\section{2-Oxoglutarate dehydrogenase activities}

Oxidation of 2-oxoglutarate using DCPIP as hydrogen acceptor led to the formation of succinate, identified by paper chromatography. Extracts of all strains possessed a similar order of 2-oxoglutarate dehydrogenase activity (Table 5).

\section{Table 7. Oxaloacetate decarboxylase activities of extracts of acetic acid bacteria}

Warburg vessels contained in $3.0 \mathrm{ml}$. final volume: cell extract; potassium acetate buffer (pH 5.6; $100 \mu$ mole); $\mathrm{MnSO}_{4}(1 \mu \mathrm{mole})$; and oxaloacetate (pH 5.6; $10 \mu$ mole added from side arm). Temperature $35^{\circ}$. Activity is given as $\mu$ moles $\mathrm{CO}_{2}$ evolved $/ \mathrm{hr} / \mathrm{mg}$. protein, and is corrected for spontaneous decomposition of oxaloacetate.

\begin{tabular}{|c|c|c|c|}
\hline Extract from & $\begin{array}{c}\text { Protein } \\
\text { added (mg.) }\end{array}$ & $\begin{array}{c}\mu \mathrm{l} . \mathrm{CO}_{2} \\
\text { evolved } / \mathrm{hr}\end{array}$ & $\begin{array}{c}\text { Oxaloacetate } \\
\text { decarboxylase } \\
\text { activity }\end{array}$ \\
\hline \multicolumn{4}{|l|}{ Lactaphiles } \\
\hline A. acidum-mucosum & $0 \cdot 162$ & $\mathbf{5 7}$ & $15 \cdot 6$ \\
\hline A. ascendens & $\mathbf{0} \cdot \mathbf{3 1 2}$ & 47 & $6 \cdot 9$ \\
\hline A. mobile & $0 \cdot 742$ & 354 & $21 \cdot 3$ \\
\hline 4. oxydans & $0 \cdot 612$ & 334 & $\mathbf{2 4} \cdot \mathbf{4}$ \\
\hline A. rancens & 0.486 & 175 & $16 \cdot 1$ \\
\hline \multicolumn{4}{|l|}{ Glycophiles } \\
\hline A. capsulatum & $0 \cdot 662$ & 10 & $0 \cdot 7$ \\
\hline A. gluconicum & $0 \cdot 414$ & $\mathbf{3 8}$ & $4 \cdot 1$ \\
\hline A. suboxydans & 0.435 & 37 & $3 \cdot 8$ \\
\hline A. turbidans & 0.497 & 14 & $\mathbf{1} \cdot \mathbf{3}$ \\
\hline A. viscosum & 0.498 & 12 & $1 \cdot 1$ \\
\hline
\end{tabular}

Table 8. Isocitrate lyase activities of extracts of acetic acid bacteria

Reactions were carried out at $22^{\circ}$ and $\mathrm{pH} 6 \cdot 85$ in $1 \mathrm{~cm}$. quartz cuvettes containing, in a final volume of 3.0 ml.: cell extract; phosphate buffer (pH 6.85, $200 \mu \mathrm{mole}$ ); DL-isocitrate (pH 6.85, $5 \mu$ mole); $\mathrm{MgCl}_{2}$ (15 $\mu$ mole); L-cysteine ( $\mathrm{pH} \mathrm{6.85,6} \mu$ mole); and phenylhydrazine (10 $\mu$ mole). Reactions were initiated by addition of cell extract and their progress followed by measurement of increase in extinction at $324, \mathrm{~m} \mu\left(\mathrm{E}_{\mathbf{3 2 4}}\right)$ over that of a blank containing no substrate. Activity is given as $\mu$ mole of glyoxylate produced $/ \mathrm{hr} /$ $\mathrm{mg}$. protein. The molar extinction coefficient of glyoxylate phenylhydrazone is $1.7 \times 10^{4}$ (Dixon \& Kornberg, 1959).

$$
\begin{array}{lcc}
\text { Protein } & \text { Increase in } \mathbf{E}_{\mathbf{3 2 4}} & \\
\text { Extract from } & \text { added (mg.) } & \text { in } 5 \text { min. }
\end{array} \text { Activity }
$$

Lactaphiles
A. acidum-mucosum
A. ascendens
A. mobile
A. oxydans
A. rancens

$\begin{array}{lll}0.86 & 0.069 & 0 \cdot 17 \\ 0.78 & 0.046 & 0 \cdot 13 \\ 0.74 & 0.091 & 0.26 \\ 0.61 & 0.020 & 0.70 \\ 0.97 & 0.069 & 0.15\end{array}$

Glycophiles: reaction mixtures contained $0 \cdot 24-1.98 \mathrm{mg}$. protein added as enzyme extract, but no activity was detected in $10 \mathrm{~min}$. 


\section{Oxaloacetate decarboxylase activities}

Because of its possible influence on assays of citrate synthase by the method of Ochoa et al. (1951) already mentioned, assays of oxaloacetate decarboxylase activities were done with freshly prepared bacterial extracts. Table 7 shows that extracts of lactaphiles were more active in decarboxylating oxaloacetate than were those of glycophiles. Action took place optimally at $\mathrm{pH} \mathrm{5 \cdot 6}$ and was stimulated by addition of $\mathrm{Mn}^{2+}$. Activity of the extracts diminished rapidly on storage even at $-15^{\circ}$.

\section{Isocitrate lyase and malate synthase activities}

These enzyme activities were tested by the methods of Dixon \& Kornberg (1959). The results (Table 8) show that extracts of lactaphiles, but not of glycophiles, possessed isocitrate lyase activity. Malate synthase activity was not detected in extracts of either lactaphiles or glycophiles, although an extract prepared from a strain of Acetobacter aceti grown on Hoyer's ethanol +inorganic salts medium (Frateur, 1950) had an activity of $67 \mu$ moles malate synthesized/hr/mg. protein.

The organisms used in the present work grew, at best, only feebly on the culture medium when acetate replaced glucose and lactate as energy source, although Brown \& Rainbow (1956) found that acetate could stimulate growth of lactaphiles in a casein hydrolysate medium. The lack of malate synthase in organisms grown in glucose + lactate may well be the reason why our lactaphiles did not grow on ethanol or acetate as sole carbon source (Brown \& Rainbow, 1956). Acetobacter aceti, however, possesses both malate synthase (see above) and isocitrate lyase (Smith \& Gunsalus, 1955) and therefore grows on acetate as sole carbon source (Frateur, 1950).

\section{DISCUSSION}

The results may be summarized conveniently by Table 9 , which shows that all the lactaphilic acetic acid bacteria examined possess the enzymic equipment for carrying out the reaction sequence of the TCA cycle. In contrast, the glycophilic strains were in general much less well endowed with these enzymes, especially citrate synthase, aconitate hydratase, fumarate hydratase and L-malate dehydrogenases, while isocitrate dehydrogenase activity was not detected in any glycophilic extract. In the glycophiles, only the 2-oxoglutarate and succinate dehydrogenase activities were of a similar order to those found in lactaphiles. As a lactaphile, Acetobacter mobile was somewhat exceptional in that, although all the enzymes of the cycle were detected in it, their activities were considerably lower than those of the other lactaphiles and, in two cases, lower than those of glycophiles. A. mobile thus appears to have properties relating it to the glycophiles, as had already been noted from nutritional studies (Rainbow \& Mitson, 1953).

There are previous reports dealing with the TCA cycle in acetic acid bacteria. Thus, its presence was reported by King, Kawasaki \& Cheldelin (1956) in Acetobacter pasteurianum, by Rao (1955) in $A$. aceti and by Stouthamer (1959) in strains of Frateur's (1950) oxydans and mesoxydans groups. All these appear to be 'overoxidizing' (i.e. they oxidize acetate to $\mathrm{CO}_{2}$ and water) strains of Acetobacter, which fall into our lactaphilic group. On the other hand, reports on strains of Frateur's 'non-over-oxidizing' suboxydans group consistently indicate that they lack the 
TCA cycle (King \& Cheldelin, 1952; Stouthamer, 1959). The present results tend to bear out these contentions, although it remains possible that members of the suboxydans (glycophilic) group have severely restricted ability to carry out the reactions of the TCA cycle, rather than that they completely lack this ability. In particular, a more exhaustive search for isocitrate dehydrogenase activity in glycophylic extracts is desirable. The results are also consistent with the view (Rainbow \& Mitson, 1953; Brown \& Rainbow, 1956; Cooksey \& Rainbow, 1962) that the

\section{Table 9. Comparative activities of TCA cycle enzymes in extracts of acetic acid bacteria}

For each enzyme, activities are expressed relative to that of the most active extract (100). C, citrate synthase; $A$, aconitate hydratase; ID/NAD and ID/NADP, isocitrate dehydrogenase (NAD- and NADP-linked); OD, 2-oxoglutarate dehydrogenase; SD, succinate dehydrogenase; $\mathrm{F}$, fumarate hydratase; $\mathrm{MD}$, L-malate dehydrogenase (DCPIPlinked).

Lactaphiles
A. acidum-muco
A. ascendens
A. mobile
A. oxydans
A. rancens
Glycophiles
A. capsulatum
A. gluconicum
A. suboxydans
A. turbidans
A. viscosum

$\begin{array}{rr}\mathrm{C} & \mathrm{A} \\ 48 & 100 \\ 100 & 80 \\ 16 & 8 \\ 79 & 98 \\ 51 & 7\end{array}$

A
100
80
8
98
72

$\begin{array}{rr}\text { ID/NAD ID/NADP } \\ 7 & 93 \\ 7 & 100 \\ 4 & 10 \\ 100 & 38 \\ 11 & 44\end{array}$

\begin{tabular}{|l|}
\hline OD \\
\hline 58 \\
92 \\
15 \\
63 \\
68
\end{tabular}

$\begin{array}{rrr}\text { SD } & \text { F } & \text { MD } \\ & & \\ \mathbf{4 5} & \mathbf{3 7} & \mathbf{2 3} \\ \mathbf{1 0 0} & \mathbf{5 6} & \mathbf{2 1} \\ 64 & 16 & \mathbf{3} \\ \mathbf{3 6} & 100 & 100 \\ 74 & 45 & 8\end{array}$

lactaphilic and glycophilic acetic acid bacteria are two nutritional and biochemical types, corresponding respectively to the genera Acetobacter and Acetomonas as defined by Leifson (1954) and by Carr \& Shimwell (1961). Nevertheless, this view does not preclude the possibility of the existence of forms, like our $A$. mobile, possessing properties intermediate between those of the two groups.

It is interesting that only Acetobacter acidum-mucosum of our strains possessed an NADP-dependent L-malate dehydrogenase, although Rao (1955) found a similar enzyme in $A$. aceti. All other strains, and $A$. acidum-mucosum itself, oxidized L-malate possibly in a cytochrome-dependent system in which DCPIP or molecular oxygen acted as terminal acceptor. Two malate oxidizing systems have also been described in Pseudomonas ovalis by Kornberg \& Phizackerley (1961) but, in this case, the nicotinamide nucleotide-linked enzyme was an oxidative decarboxylase.

We are indebted to the Department of Scientific and Industrial Research for a grant to P.J. le B.W.

\section{REFERENCES}

Brown, G. D. \& Rainbow, C. (1956). Nutritional patterns in acetic acid bacteria. J. gen . Microbiol. 15, 61.

Carr, J. G. \& Shimwell, J. L. (1961). The acetic acid bacteria, 1941-1961: a critical review. Antonie van Leeurvenhoek, 27, 386.

Cooksey, K. E. \& Rainbow, C. (1962). Metabolic patterns in acetic acid bacteria. J. gen. Microbiol. 27, 136. 
Dixon, G. L. \& Kornberg, H. L. (1959). Assay methods for the key enzymes of the glyoxylate cycle. Biochem. J. 72, 3 P.

Fewster, J. A. (1958). Growth of Acetobacter suboxydans and the oxidation of aldoses, related carboxylic acids, and aldehydes. Bioch. J. 69, 582.

Frateur, J. (1950). Essai sur la systématique des acetobacters. Cellule, 53, 287.

Fuller, R. C. \& Kornberg, H. L. (1961). A possible route for malate oxidation by Chromatium. Biochem. J. 79, 8 P.

Hollunger, G. (1955). Guanidines and oxidative phosphorylation. Acta pharm. tox., Kbh. 11, suppl. 1.

King, T. E. \& Chelderin, V. H. (1952). Oxidative dissimilation in Acetobacter suboxydans. J. biol. Chem. 198, $12 \%$.

King, T. E. \& Cheldesin, V. H. (1956). Solubilization of the cytochrome(s) of the particles from Acetobacter suboxydans. Fed. Proc. 15, 288.

KIng, T. E., Kawasaki, E. H. \& Chembenin, V. H. (1956). Tricarboxylic acid cycle activity in Acetobacter pasteurianum. J. Bact. 72, 418.

Kornberg, H. L. \& Phizackerley, P. J. R. (1961). Malate oxidation by Pseudomonas spp. Biochem. J. 79, 10 P.

Lemson, E. (1954). The flagellation and taxonomy of species of Acetobacter. Antonie van Leeurvenhoek, 20, 102.

Lowry, O. H., Rosebrough, N. J., Farr, A. L. \& Randall, R. J. (1951). Protein measurement with the Folin phenol reagent. J. biol. Chem. 193, 265.

Massey, V. (1953a). Studies on fumarase. 2. The effects of inorganic anions on fumarase activity. Biochem. J. 53, 67.

MAssey, V. (1953b). Studies on fumarase. 4. The effects of inhibitors on fumarase activity. Biochem. J. 55, 172.

Morrison, J. F. (1954). Studies on aconitase. XXXIV. The purification of aconitase. Biochem. J. 56, 44.

Ochoa, S., Stern, J. R. \& Schneider, M. C. (1951). Enzymic synthesis of citric acid. 11. Crystalline condensing enzyme. J. biol. Chem. 193, 691.

RACKER, E. (1950). Spectrophotometric measurements of the enzymatic formation of fumaric and cis-aconitic acids. Biochim. biophys. Acta, 4, 221.

Rainbow, C. \& Mitson, G. W. (1953). Nutritional requirements of acetic acid bacteria. J. gen. Microbiol. 9, 371.

Rao, M. R. R. (1955). Pyruvate and acetate metabolism in Acetobacter suboxydans and Acetobacter aceti. Diss. Abstr. 15, 675.

SANAdI, D. R. \& LrTrlefield, J. W. (1951). Studies on $\alpha$-ketoglutaric acid oxidase. 1. Formation of 'active' succinate. J. biol. Chem. 193, 683.

Shrmwell, J. L. (1958). Flagellation and taxonomy of Acetobacter and Acetomonas. Antonie van Leeuwenhoek, 14, 187.

Singer, T. P. \& Kearney, E. D. (1957). In Methods of Biochemical Analysis, vol. 4, p. 307.

SmrrH, I. (1958). Chromatographic and Electrophoretic Techniques. London: W. Heinemann Ltd.

Smith, L. (1954). Bacterial cytochromes. Bact. Rev. 18, 106.

Smith, R. A. \& Gunsalus, I. C. (1955). Distribution and formation of isocitritase. Nature, Lond. 175, 774.

Stadtuan, E. R. (1957). In Methods in Enzymology. Ed. by S. P. Colowick \& N. O. Kaplan, vol. 3, p. 931. New York: Academic Press Inc.

Stovthamer, A. H. (1959). Oxidative possibilities in catalase positive Acetobacter species. Antonie van Leeuwenhoek, 25, 241.

Stouthamer, A. H. (1961). Glucose and galactose metabolism in Gluconobacter liquefaciens. Biochim. biophys. Acta, 48, 484. 